\title{
A MODEL ACT TO ESTABLISH A COURT FOR A METROPOLITAN DISTRICT
}

We build our cities first and do our city planning later. The numerous distinct or slightly related courts of the typical large city illustrate the development of institutions without an inclusive aim or unity of design. In no city is the present complex system of courts one that could be deliberately imposed. In no city is the present system one wholly approved by any body of citizenship. At the present time there is a restlessness that denotes instability. Complexity is growing in response to the demand for specialization. Unless the judicial function is viewed in an inclusive way change is likely to afford but little relief from present shortcomings.

In view of the certainty of experiment in this field the American Judicature Society undertook as one of its first tasks to correlate experience and to project a unified system of courts calculated to meet all the various needs involved. After more than two years of study in which representative lawyers, judges and political organizers participated, the Society has formulated its views in a model act to establish a court for a metropolitan district. The term district is employed because of the need for including as a unit of administration all of the suburbs lying close to the typical large city.

The act is based upon belief in the peculiar needs of the large center of population as opposed to the needs of the less populous parts of the state. Specialization is an impressive need in the large city. A mistaken attempt to meet this need results in the creation of separate and more or less unrelated courts which make the machinery of justice increasingly complex.

The first step toward creating a correlated system lies in consolidating all the trial courts within the metropolitan district into a single organization. This unified local court is to have no competitor in the trial of causes.

The demand for specialization is to be met through two features; certain broad divisions, well defined by the nature of the service rendered, are effected by the act; within these divisions as many branches as may be desired are to be established by administrative orders. The act provides five such general divisions, as follows: 
I. The Equity (or Chancery) division. It is not intended by the creation of this division to-negative the worthy endeavor to merge law and equity. It merely recognizes as a practical fact the need for specially trained judges in the trial of causes involving the peculiar remedies which had their origin in the Court of Chancery.

2. The Probate and Domestic Relations division. No organized court can fail to provide specially for handling the offenses which undermine the integrity of the family. Offenses against minors, desertion, non-support, and certain similar offenses to be defined constitute together a body of causes which cannot be handled properly in police courts; they must be segregated in a division to which is given divorce litigation. The business of the juvenile court will also naturally be handled in the same division. It is the theory of the act that all these matters may well be handled by a division which has charge of probate matters.

3. The Civil Jury division. This department is sufficiently described by its name. To it would fall all the civil causes involving the use of a jury, and the need for specialization as between contract and tort causes is to be met by intra-divisional specialization.

4. The Civil Non-jury division. All the remainder of civil causes would be taken care of by branches of this division based upon executive orders and readily altered as circumstances indicate.

5. The Criminal division. Within this division such branches as experience shows a need for would be established.

In even the largest city five such general divisions would suffice; the small number and obvious character of each should prevent confusion in the public mind.

In a smaller city, one with twenty or twenty-five judges, three divisions might be enough, while with fifteen judges or less there might well be no fixed divisions at all. In such a compact body . of judges the government of the court, to be explained later, could rest upon all equally.

Within each of these divisions there can be as many branches as convenience may dictate. The branches should depend only on administrative orders changeable at will. Power to create such branches is contained in the provisions respecting the classification and distribution of the business of the division upon various separate calendars.

Our aim must be toward specialist judges as opposed to the present tendency to create special tribunals in which judges are 
placed with little or no reference to their individual capabilities. Genuine specialization is dependent upon the special training and personal qualities of the judge. Only by due recognition of these facts can we escape the waste of judicial experience which is to-day one of the chief and least excusable causes for inefficiency.

Such an organization will not run itself any more than an industrial organization devoted to such highly complex duties would run automatically. Conspicuous leadership is obviously required. In breaking away from tradition in an attempt to secure conscious and expert administration the tendency has been to jump to the other extreme and concentrate authority unduly. The Municipal Court of Chicago is the best example. In this court the executive is required to establish branches and calendars and direct the activities of thirty judges having a wide range of work, though not as wide as that presumed by the model act, for the Chicago court has no chancery or felony jurisdiction. Such concentration of authority implies extraordinary capacity on the part of the head of the court. Any model organization must be formed with reference to what may reasonably be expected of human nature.

A scheme for self-government of the metropolitan judicial machine readily presents itself. Each division must have its own divisional chief, or presiding justice. These presiding justices together naturally form the representative judicial council, or executive body. By so constituting the judicial council it has a representative constantly in every division and every division has a representative in the governing body.

It only remains to provide a chief executive who will preside over the judicial council and see that its will is executed. This official head of the court is called in the act the chief justice, in conformity with American practice, though president judge or some other title might be more fitting.

It is provided that the electorate shall choose the chief justice directly. The office is one calling for executive ability in preeminent degree and this is the characteristic which voters are best qualified to detect.

Whatever be the method of selecting associate judges, it is clear that so much depends upon the personality of the presiding justices, constituting together the central authority of the court, that they should be chosen from the entire body of judges by the chief justice. And there should be no traditional check upon such appointment for that would provoke politics within the 
organization. At the same time it is not desirable that the chief justice should be able to revoke the commissions of presiding justices at will. Such power would make the council a mere tool of the chief justice. To make the position of presiding justice irrevocable during the entire term of the incumbent would be equally unfortunate, for a new chief justice might find himself a minority in the judicial council throughout his entire term.

The act provides. a method which escapes the evils of both these suggestions. It gives to the chief justice the power to name a presiding justice for a definite term not longer than the term of the chief justice, who, being an elected official, would presumably hold for a term of four or six years. The newly elected chief justice wotld then have the power to make over the judicial council during his term bit the presiding justices once selected would not hold at his pleasure. His power to alter the personnel of the council in the course of time would give him enough of a hold to insure reasonable tractability, while the fact that he could not depose one of his appointees guarantees a sufficient measure of independence in the council. This arrangement should afford just that degree of poise between officials sharing a common responsibility which is requisite for harmonious coöperation.

Judges of the consolidated courts continue for the remainder of their terms as judges of the Metropolitan Court. They are to be assigned by the chief justice to the various divisions to the number specified for each by the act. The judicial council is permitted to change the number of judges in divisions if such becomes advisable by reducing the number in any division when a vacancy occurs in that division and adding one judge to another division.

While the need to assign judges to special work is paramount there must be a reasonable limitation as a guaranty to the associate judge that he will not at some time be arbitrarily removed from the work in which he has specialized. This is afforded by the provision that the chief justice may transfer judges from one division to another only with the consent of the presiding justice of at least one of the divisions to be so affected. This power of the chief justice is supplemented by a power to make temporary transfers of any judge (except presiding justices) for a period not exceeding six months, and to require any judge "who shall not for the time being be occupied in the transaction of any business assigned to the division to 
which he may be regularly attached, to take part in the sittings of any branch or of any division" of the court. In this manner the right of the individual judge to work in the field for which he is best fitted is protected and at the same time the exigencies of administration are met so that there will be no congested branch as long as there are judges not fully occupied.

Assignment within the division rests with the presiding justice of the division, subject to the right of the chief justice to exercise this power, and it is effected as a practical matter under a section which gives the presiding justice the power to classify the business of his division and distribute it "upon different calendars, to be called by different judges, as he shall deem proper and expedient."

In such manner is specialization according to a definite and responsible management made possible. It may extend to the most minute degree so that every judge has a special calendar, if desired. At the same time the judges constitute a fluid working force which can be directed from time to time in such manner that the court will be always working at its maximum of output.

At the present time the rural distinction between judges and inferior court judges persists in every American city. It is plain that any division of the working force into two classes of judges, one to have limited judicial power, prevents the flexibility that is necessary to the highest efficiency.

The inferior court is a necessary outgrowth of primitive conditions. In communities having only a small amount of judicial business economy requires an inferior magistracy because the small cause cannot stand the cost of removal to a distance, nor can it, in many instances, permit of delay.

The reasons for a departure from custom in the large city may be stated briefly as follows:

I. The historic division between general and limited jurisdiction rests upon economy of administration. In the large city the reason has ceased to exist. The only true economy lies in getting a right and lasting adjudication in the first instance and this requires exceptional men. A very small percentage of appeals destroys the economy of employing inferior judges. In so far as our present judicial hierarchy in the large city is a negation of this principle it must be destroyed.

2. It is to-day impossible to say what is the more important work in a city court, but it may be observed that the judge sitting in the criminal court of first 
instance, receiving the pleas of youthful offenders, occupies a most important rôle from a civic and social standpoint. Inferior personality in this field means a failure of civilization.

3. It is unwise to say that the hearing of small claims is a petty branch of judicial business for the great mass of people who have no other causes. Failure to provide a judge of character and standing drives such litigants to a formality of trial which makes efficiency impossible.

4. Causes are likely to partake of the nature of two or more classes and efficient adjudication requires handling of the greater with the lesser issues. Many of the causes of a domestic relations branch are seemingly trivial but some require divorce jurisdiction for a solution. The judge of limited jurisdiction is prevented from doing a judge's full duty in these causes even if he be not inferior in personal ability.

These considerations have resulted in giving every judge of the Metropolitan Court complete trial jurisdiction. The fact remains undeniably that some branches of the work require less training than others, that judges will vary in capacity, and that the distinction between those of brief experience and those of long training will exist in the judicial field as in all others. Recognition is given to these necessary conditions by providing two classes of judges to be known as senior and junior judges.

A very practical reason for doing this arises from the presumption that the merging of all the courts of any city will involve bringing in a number of judges previously sitting in inferior tribunals. These judges have received smaller salaries than judges of full trial jurisdiction. The proposal to raise their authority and compensation en bloc would arouse great opposition. The position of junior judge permits of their inclusion and subsequently the character of work which they will engage in will depend upon their assignment by the head of the court. It is reasonable to suppose that many of them would develop qualities entitling them in time to the highest places in the court. By giving them full trial jurisdiction they are made available for such service as they may become qualified to render. On this point it is well to quote from the note to section five of the act:

"Where there is a large volume of judicial business of all sorts to be handled by a large corps of judges and the judicial business differs widely in character, a great deal of it may be satisfactorily done by younger men of 
less judicial experience who start at a less salary and commence with the handling of the less difficult, the less responsible and often less agreeable work, with a view to developing a capacity for handling the more difficult, more responsible and often more agreeable business of the court. The situation is not different from that in any executive office or in a firm with a large number of partners. No one thinks of paying the same salary to all the members of an executive force or dividing all the profits equally among. all the partners. The principles which obtain as a matter of course in the organization of a private enterprise apply to the public business of administering justice in a metropolitan district with a large corps of judges and an enormous volume of judicial work.

The saving of money spent in salaries is not the only reason for having junior judges. Human nature is such that it needs the stimulus of possible promotion. To give a man a position in which he is to stay for the rest of his life with no promotional steps ahead which he may compete for is to discourage endeavor and stifle ambition. This is recognized in every business enterprise. It is recognized in the large firms having many partners. It is of the utmost importance to recognize it in the organization of a corps of judges.

The whole matter may be thus summed up. To give all the judges the same salary at once is to overpay some and underpay others. That course is demoralizing to the worker. It ignores the fact that men need to strive for promotion which is fairly within reach.

It should be noticed that the plan of having senior and junior judges does not in the least interfere with the plan of requiring the best and most highly paid judges to hear the less difficult and less agreeable class of judicial causes. It does contemplate that when the best men in the court have heard such causes and established the best methods and rules for administering justice in them, younger men with talent, but with less judicial experience, shall handle them."

There is a considerable amount of work now done by judges which could as well be done by assistants but lack of organization has prevented the intelligent employment of such assistants. In some states the use of masters resulted in such dissatisfaction that the very word is anathema and the entire subject is obscured. The trouble was due to a delegation of the essential judicial function to the assistant. The diffused and uncertain responsibility resulting from this practice is rightly condemned. But all that is required to permit the court to avail of the obvious benefit of judicial assistants is to prevent abuse of the system. 
A great deal of the time of the judge, who, as a highly trained expert should concentrate his energies on strictly judicial work, can be saved if the ministerial part of the work is performed by a trained assistant. In an organized court it is readily possible to curb any tendency toward evil. The faults frequently attributed to referees will also disappear when they are specialists attached permanently to an organized court and subject to supervision and discipline.

In the act these assistants are called masters at the risk of attaching to the position the ancient odium. The name "assistant judges" would probably lead more directly to misapprehension of their functions. The important matter, regardless of name, is to relieve judges of ministerial work and conserve their energies for the more difficult rôles not easily filled.

The act provides that there shall be attached to the Metropoli$\tan$ Court such number of masters, not exceeding a stated maximum, as the judicial council shall determine, and that they shall perform such duties as are prescribed by the act or by any rules or orders of the council. This permits of the use of assistants who will increase the working capacity of certain judges and who will develop a high degree of efficiency within a narrow field, but, by reason of steady employment and long tenure, will be obtainable at a salary considerably less than that paid a junior judge.

There are two features of the act of great importance which rest upon well settled, though recent experience in organized city courts in this country; these are the compiling and publication of statistics, and the meetings of judges. The only courts in the country which are keeping and publishing statistics are the few recently created municipal courts; the general lack of records and information has been considered one of the greatest shortcomings of American courts as compared with those of all other countries.

The facts concerning the work of the courts are greatly needed as a basis for social and criminal legislation. Without them we grope in the dark and many a weird enactment attempts to fill an imagined need. The lack of consistent data prevents the judges themselves from seeing their function in an inclusive way. It results in much unmerited criticism of judges. Without recorded data there can be no definite standards of accomplishment. Courts operating without statistics are like ships bound for an unknown port over uncharted seas. 
The chief justice is made responsible in this act for compiling records, for he is required to submit at the annual meeting a report which shall contain full statistics concerning the business done by the court and by each permanent division for the year ending January first next preceding, and the state on that date of all the dockets. The data shall be collected under the five following heads: litigation, efficiency of personnel, social, criminal, and financial.

The chief justice will presumably receive weekly or monthly reports from presiding justices which will keep him in close touch with every branch and afford data for the judicial council to rely upon in its general supervision of the court.

The annual meeting brings together all of the judges for a general survey of accomplishments and a discussion of any matter whatsoever pertaining to the administration of justice. Judges of divisions are required to meet at least once a month except in August. "At such meetings the judges of division shall receive and investigate, or cause to be investigated, all complaints presented to them pertaining to said division and to the officers thereof and shall take such steps by law as they may deem necessary or proper with respect thereto."

It is difficult to exaggerate the importance of meetings of judges to whom are given responsibility and authority. Out of such meetings grows that esprit de corps which must be realized if courts are to function in a conscious, uniform and impartial manner. The experience and the conscience of the best equipped judges becomes the property of all. Methods of administration are standardized and made impersonal. The judge who is following a practice objectionable to the public or to his colleagues is brought into line when he must defend his conduct before qualified critics. At the same time it affords to every judge a criticism which is expert, open and fair.

The solidarity thus obtained gives judges a needed protection against unfair attacks. The bulldozing politician is made to realize that he is opposing a strong institution instead of a single judge so that the independence which is wholesome is insured. The litigant with a grievance, whether real or imagined, is given a privilege to which he is entitled and which goes far to bring the public into sympathy with their judges.

Of course the public will have opportunity to make complaint at any time to the chief justice or judicial council. This is a necessary and proper privilege. Its work in practice has been 
thoroughly demonstrated in organized municipal courts now in operation in a number of cities. In no other way can the confidence and approbation which the work of faithful and competent judges deserves be secured on a broad democratic basis.

Taken together the meetings and statistical records constitute a great self-disciplining force. They make the court sensitive, on the one hand, to intelligent public opinion, and on the other confer upon the judges the solidarity and power of a strongly knit and successful organization.

The history of organized courts is not yet ten years old but it has already demonstrated an unexpected possibility for inventing economical and efficient methods of administration. The Municipal Court of Chicago, for instance, has a dozen specialized branch courts, created by executive order, and filled by special assignment. The most striking instance of invention in the field of judicial administration occurred in the creation of the branch court of Domestic Relations. Formerly a variety of criminal and quasi criminal causes, not supposed to be related in character, were dealt with in a number of out-lying police station branches. These causes all related to the integrity of the family. When they were put on a single calendar and heard at a central and specialized branch by a selected judge, consistent and remedial action became possible for the first time.

An interesting example is afforded by the Speeders branch of the same court. Offenses against automobile laws and ordinances could not be treated consistently when they were in the hands of a dozen separate judges sitting in scattered police courts. The instinct of the judge to keep uppermost the general public's right to have a rigid enforcement of law was too often ridden down by the pressure which the individual offender was able to concentrate upon this outpost of the court. The certainty of punishment which is the first essential to secure obedience to law was lacking.

When all such cases were brought in the new centralized court the offender found a judge selected for the work and shouldered directly with the responsibility of making life safer on city streets. Immediately fines became large enough to accomplish their purpose. The influential offender and his alderman found themselves inferior to the morale of the court.

There is a lesson in this bit of history. All over the country we grieve over lawlessness, even when participating in it. Adhering to the theory of government by laws and not by men 
we pile statute on statute, and penalty on penalty, until our acts and ordinances make a body of law impressive in bulk and increasingly impotent in execution.

The act recognizes fully the present widely accepted belief in the need for home rule in the judicial establishment. In both code and common law states a great body of statutory procedural rules has been evolved. These rules are presumed to suit equally well the courts of the city and those of rural counties. In states largely rural in character fair success is still observable under this system, especially where the citizenship is of a relatively high order. In the larger cities the system most clearly shows its defects. Legislatures composed mostly of country members are peculiarly unfit to lay down regulations to city courts. The tremendous growth of statutory rules is due to the absence of direct and responsible administrative control on the part of courts. The result is inevitably a lowering of the power, the dignity, and the responsibility of the judicial office.

City courts must have a large measure of home rule. They must be able to recognize local needs and alter rules to meet changing conditions. The work is too delicate to permit of success at the hands of an inexpert body. There can never be that measure of responsibility essential to successful adjudication and to the dignity of the judicial institution until judges have the power to make the lesser and more numerous procedural rules fit the needs of administration.

On the presumption that such a metropolitan court will be established in a state which has not restored to its courts this ancient prerogative, the act confers rule-making power upon the judicial council of the new court. The assumption is that a short practice act, embodying the more important and seldom altered rules, will be enacted at the same time as the judicature act proper, and that a schedule of rules will be adopted as the first rules under the act. The power to alter and amend the schedule is conferred upon the judicial council.

Of course the greater part of existing procedure is suitable and this, though abolished as statute law, remains in force as rules of court, until the judicial council shall see fit to alter it. Only the statutory procedure in conflict with the short act and schedule of rules is abolished. The transfer can be made with a minimum of inconvenience. A great deal is gained from the mere fact that this body of existing procedure, already in force, and not disturbed, is restored to the court's authority. 
The legislature of course is not to be deprived of its ultimate authority but there is ample proof in support of the expectation that this body will exercise restraint once the control of rule making is placed in expert and responsible hands. Considerable formality is involved in the altering of procedure by the court. Notice of the proposal to make any rule must be published at least forty days in advance and copies of the proposed draft are to be furnished at a small fee. Any person may offer suggestions in writing. The rules, unless an emergency exists, are to take effect on August I after the time of making them. The actual operation under this power will doubtless mean participation by a committee of the local bar association.

The act consolidates all clerks' offices and provides for a single clerk to be appointed by a majority of the judicial council and to hold at the pleasure of the council. A central clerk's office and branch offices shall be established at such places as the council may by rule determine. The chief justice is given power to make regulations with respect to the appointment, removal, and duties of persons to keep order in the various branches and in any other matters necessary or incidental to the use or management of the court.

For the benefit of cities not already suitably provided there is a chapter of the act providing for jury commissioners.

An interesting provision is found in the chapter on salaries whereby increased pay follows the normal increase in efficiency arising from experience. The minimum salary of the new judge is increased by $\$ 500$ a year for every three-year period until a maximum is reached and the same provision applies to the sal-. aries of masters.

A simple pension system is provided; upon reaching the age of sixty-five years, a judge who has served ten years may retire on half pay; at the age of seventy, after twenty years' service, he may retire upon full pay. Any judge entitled to retire under these terms may be so retired at the option of the judicial council for the good of the service.

Penalties are provided to prevent any judge, master, clerk or employee from soliciting any assessment or contribution for political purposes or from making any payment or promise for such purposes.

Such a judicature act could not be adopted in any state without constitutional change; nor could any organization worth serious effort be effected in conformity with existing limitations 
in the organic law. The conflict is an obvious but not necessarily a deep one, for the proposals are not hostile to any constitutional principles. They are balked not by the spirit of any constitution, but by its minor petrifactions.

The Bulletin contains suggestions concerning the most convenient method for instituting such legislation in connection with a constitutional amendment and the act is in fact made a schedule to a proposed amendment.

The foregoing brief description pertains to the revised act as published in Bulletin IV-B, American Judicature Society. The parts relating to the selection and retirement of judges, upon revision, were published separately in Bulletin IV-A. The organization features of the act are not dependent upon any particular method of selecting judges. In this field local traditions and prejudices are strong. In some states there is entire satisfaction with a system of appointment by the governor, either for a stated term, or for good behavior. In other states the elective plan is affording such a degree of satisfaction that there is no need to suggest a departure and at any rate the scheme of organization should not be made to wait upon political reform.

These matters are discussed at length in Bulletin IV-A. An important point is made in showing that the appointive and elective systems, as at present in use, do not by any means comprise all the possibilities of the situation, nor do either of them meet the desideratum of having trial judges selected by an expert (i. e., one entirely competent to weigh the varying talents of available candidates) who is also responsible for the due administration of justice.

It has been impossible heretofore to formulate such an idea for the reason that we have never had any person so responsible. But with the coming of the organized court there exists necessarily an executive head to whom the public may look for satisfactory administration. The way to make his responsibility most definite and constructive is to give him a considerable share in the work of selecting judges.

One of the plans given statutory form in Bulletin IV-A provides that the chief justice shall be elected for a comparatively brief term, as four years, and that he shall appoint to fill vacancies occurring during his term. The motive of the chief justice to surround himself with capable judges acceptable to the public and qualified to make his administration successful would be infinitely greater than the force which leads governors to make wise selections. 
In a large city there would be normally only a few such appointments during the term of a chief justice because vacancies would occur less frequently under any reasonable form of tenure as soon as selection were expert and because the absurd waste of judicial experience now common under the elective system must be done away with.

It is quite impossible for us to conceive of an appointing power without a check and yet a check of the customary sort would doubtless be accompanied by log-rolling. The murky ways of politics may be avoided by an ingenious check which limits the chief justice, for part or all of his appointments, to an eligible list of candidates. According to this plan there is a public list of lawyers receptive to judicial honors double in number to the sitting judges in each division of the court. Names are put on the eligible list by the judicial council as vacancies occur.

Such a list would doubtless contain the names of the most able lawyers available to public service; it would impose a sufficient check upon the appointing power and yet not unduly limit the reasonable freedom of the chief justice.

In the present half-organized and chaotic condition of the bar of a large city such a list would be like ballast in a cranky ship. The list would constitute a roll of honor, twice as numerous as the local bench, and its members, chosen presumably from the most active practitioners, would prove friends of the court in a very practical way.

With a suitable form of selection and subsequent administrative leadership there would come before long a degree of public confidence now lacking so that acquiescence in long tenure would be the natural development. Meanwhile a people used to passing frequently upon judicial candidates will want to preserve this custom. To meet this demand it is proposed that appointments shall be for a definite probationary period. A confirmation by popular vote after probation would serve to continue the incumbent for a longer period, after which there may be a second vote. A second confirmation should mean a still longer term.

To carry out this idea it is provided that at every election of a chief justice there shall be submitted to the voters the names of all judges who have served three years and have not been voted upon, all who have served nine years and have once been confirmed, and all who have served eighteen years and have been twice confirmed. Coupled with each name is a statement of the 
length of time served and the simple query whether this judge shall be continued in office. Coming at stated intervals such a submission has none of the features of the judicial recall; it gives voters full power to retire an unsatisfactory judge; and it submits the name of the judge under terms far more favorable to a deliberate and just determination than is possible under the present system which compels the incumbent to compete at one or two elections with one or more envious rivals.

A proposal intended to secure a like benefit in the case of the elected judge is made in connection with an interesting discussion of the merits and demerits of the elective system as applied to the judicial office. One of the reasons for difficulty in choosing judges by election lies in the fact that a mixed question is submitted; the bringing in of rival candidates, when the incumbent is willing to continue his service, is an intimation that there should be a change. Encouragement is given to campaigning which is directed toward stirring up feeling against a sitting judge. The incumbent is in a measure running against the field. There is involved some of the most objectionable elements of the recall.

These defects are not essential to an elective system. It is possible to provide for the submission of the names of sitting judges as stated above with the difference that in case of a rejection there must then be held an election open to all candidates instead of filling the vacancy by appointment. While this would at times involve additional expense the benefits accruing would undoubtedly justify the effort and cost.

In summing up it may be noted that a first view of the organization scheme gives an impression of complexity but compared with the situation to-day in any large city it is in reality as simple as it is consistent. Perhaps the most important fact is that the judicature act merely weaves accustomed elements into a congruous whole.

For half a century and more we have attempted by minute and mandatory rules to compel judicial efficiency and we are further to-day from success than when we started. The present proposals mark a growth of political philosophy; they are aimed not at making angels of judicial officers, but of creating a machinery of justice which is workable by human beings.

The act itself studiously avoids changes in procedure, but by confirming the court organization in needed power to regulate the details of practice it paves the way to an evolution of pro- 
cedure in expert and responsible hands. In numerous ways it tends to make judicial independence genuine and practical. No presiding justice or chief justice can influence the individual trial judge with respect to his decision in any cause. The fact that the judge is part of a strong and successful institution makes for real independence, as against the dependence too often resulting from the inefficiency of the dissociated unit.

The act may be said to be derived in theory from three sources: from principles of organization worked out in business fields, from the conspicuous success of partial organization in so-called municipal courts, and from the comparative success of commissions established for mixed administrative and judicial purposes.

From the beginning of our system of courts the essential judicial function has been organized so that responsibility for decisions, as between trial judges and appellate courts, has been entirely clear. The act imposes no new or different idea in respect to this vital part of judicial procedure. But until recently there has been but a very imperfect organization of responsibility for the administrative side of the judicial function, which is of growing importance in every large city.

Analysis of existing defects in the administration of justice, including numerous phases of the work which rarely come to the attention of the representative lawyer, points to the present lack of administrative organization and direction as their pre-eminent cause. A mis-reading of the symptoms leads to apathy on one hand and bizarre proposals on the other, according to the temperament and training of the observer. Meanwhile proofs of the value of organized responsibility and business management have been supplied by the new courts of several cities. In the shortest description the purpose of the plan is to create an environment in which the individual judge will be free to reach his highest point of public usefulness.

\author{
HERBERT HaRLEY, \\ Secretary of the \\ American Judicature Society.
}

Chicago, Ill. 